\title{
The Impact of Terrorism and Military Expenditure on Economic Growth: Evidence from PANEL ARDL Model
}

\author{
Emna Saidi ${ }^{1}$, Dr. Prof. Ghazi Boulila ${ }^{2}$ \\ ${ }^{1}$ University of Tunis \\ ${ }^{2}$ The higher school of economic sciences and trade of Tunis (ESSECT)
}

\begin{abstract}
The arms industry can be considered as a double-edged sword, while some researchers see that military expenditure and arms trade can promote wars, by augmenting tensions between countries, others believe that this industry is a good strategy to guarantee order and security, or to fight terrorism.

It is also important to know that some authors believe that the direct effect of terrorism is restricted, others see that terrorism can lead to big economic losses.

Therefore, the impact of military spending and terrorism on economic growth stays always ambiguous.

Unlike the majority of studies that have compared the impact of military spending and terrorism on economic growth in low-income and high-income countries, our work aims to compare the effect of these variables on economic growth in the biggest arms importing and exporting countries during the period 1994-2017

Using a panel ARDL approach we confirmed the co-integration between military expenditure, terrorism and economic growth and we concluded that the impact of defense spending and terrorism is more undesirable in arms importing countries than in arms exporting countries:

The PMG estimator was used for arms exporting countries where defense spending has a negative and significant effect on economic growth in the short term but not in the long term. Otherwise, terrorism doesn't affect economic growth both in the long and short term. The MG estimator was used for arms importing countries: in the short term, terrorism and military expenditure don't affecteconomic growth. Conversely, in thelongterm, theireffect becomes significantly negative.
\end{abstract}

Keywords: Arms exporters and importers; Co-integration; Defense economy; MG estimator; PMG estimator. 